\title{
College Students' Perceptions toward the Multi Modal Representations and Instruction of Representations in Learning Modern Physics
}

\author{
Funda YEŞİLDAĞ HASANÇEBIं*
}

Murat GÜNEL**

\section{Suggested Citation:}

Yeşildağ Hasançebi, F., \& Günel, M. (2013). College students' perceptions toward the multi modal representations and instruction of representations in learning modern Physics. Egitim Arastirmalari-Eurasian Journal of Educational Research, $53,197-214$.

\begin{abstract}
Problem Statement: In recent years, researchers on learning have focused on learning with multimodal representation and this research has shown that when learners can interact with an appropriate representation their performance is enhanced. If students have the opportunity to interact consciously with modal representation, learning can be extended, comprehensively and deeply. This study studies the question of what would be the appropriate instructional design to scaffold such an enhancement and what would be the distribution of modes that would be found to be valuable, from students' perspective, in instruction and writing-to-learn activities, with specific regard to science education topics.

Purpose of Study: The purpose of this study was two folded; firstly, to find out the effect of instructional activities on students' understanding of modal representations and, secondly, to explore the multimodal representations that college students find effective and use in studying some of the modern physics units

Methods: This study was carried out with 80 sophomore college students in Turkey within two identical sections of introductory modern physics for an education majors course in the 2007-2008 spring semester. Three assignments were designed and implemented to explore effective practices that can help students to enhance their understanding of modal representations. At the end of the instructional stage, through survey and semi-
\end{abstract}

${ }^{* *}$ Corresponding author: Dr., TED University, Department of Primary Education. Turkey, email: murat.gunel@tedu.edu.tr

*MS. Atatürk University, Department of Science Education. e-mail: fun-

da.hasancebi@atauni.edu.tr 
structured interviews, students were asked to evaluate the value of the instructional implementations and the effective modal representations in the learning of concepts.

Findings and Results: Most of the students agreed that completing the three assignments was valuable in extending their understanding of modes; in understanding their roles in communicating ideas; in helping to scaffold their understanding, and effective usage, of modes and in increasing their knowledge with regard to modern physics units studied. In addition, students who participated in this study found the pictorial mode to be the most valuable in studying light, photo-electricity, and Compton effect units. On the other hand, students designated the textual mode as being the most valuable mode for studying the de Broglie unit. Moreover, students preferred to use picture and text in their writing-to-learn activity.

Conclusions and Recommendations: An important theme emerges when the two parts of the results are considered. That is, when opportunities are provided to students in order to analyze and evaluate scientific materials from a multimodal perspective, they can build a concrete understanding of content knowledge as well as using modal representations to communicate ideas. Furthermore, if such opportunities are extended to create writing activities with multimodal representations, students additionally benefit by building content understanding and seeing what they know and do not know about the concept. When multimodal enriched learning opportunities are provided to college students to study introductory modern physics subjects, it appears that there is a mode cluster with picture and text becoming predominant. To promote the conceptual understanding of physics, we need not only to provide robust understanding of multimodal representations but also to be aware of modal clusters from multiple angles.

Keywords: Multi modal representation, writing in science, writing-to-learn, modern physics

\section{Introduction}

Science, without language (writing, reading, speaking), cannot function (Norris \& Phillips, 2003). Writing, including text, mathematical representations, graphics, and pictures, has an important function in scientific activity, as with other forms of language. Furthermore, as Lemke (1998) has stated, "Science is not done, is not communicated, through verbal language alone. It cannot be." (p. 89). Indeed, he argues that scientists "combine, interconnect, and integrate verbal text with mathematical expressions, quantitative graphs, information tables, abstract diagrams, maps, drawings, photographs, and a host of unique specialized visual genres seen nowhere else" (p. 89). In order to understand science in its fundamental sense, as well as carry out scientific activities, one needs to be able to use writing and its components effectively (Norris \& Phillips, 2003). Consequently, using writing effectively in educational set- 
tings may be a tool for promoting scientific literacy as well as a tool for learning scientific concepts (Prain \& Hand, 1999; Yore, Bisanz, \& Hand, 2003).

Researchers in science education look to promote students' understanding of science by implementing nontraditional writing strategies as these strategies encourage and provide students with rich cognitive activities to construct scientific knowledge (Gunel, Hand, \& Prain, 2007; Hand, Prain, Lawrence, \& Yore, 1999). Furthermore, writing-to-learn activities can help students to connect science language with their daily language. Consequently, such connections via writing scaffold students' understanding of fundamental science concepts. In practice, Prain and Hand (1999) put forward several suggestions for a diversified writing activity that included the use of writing types such as brochures, letters, newspaper articles, the construction of posters, concept mapping, and computer slide-show presentations. All of these diversified writing-to-learn activities mentioned above include form of modal representations (text, graph, table, formula, etc.) to elucidate ideas in science. Thusly, promoting the integration of modal representations into writing activities can become a means to improving the learning outcome from such activities (Gunel, Atila, \& Buyukkasap, 2009; McDermott, 2009).

Multi Modal Representations and Learning Science

Researchers on learning have focused on learning with multi modal representation in recent years and this research has shown that when learners can interact with an appropriate representation, their performance is enhanced (Ainsworth, 2006). Students' competence with different modal representation and the effect of such competencies on achievement has been investigated by scholars in the area of science education (Kohl \& Finkelstein, 2005). For example, Kohl and Finkelstein (2005) investigated the relationship between success in physics problem solving and modal representations used with the problem. They indicated that students make more mistakes when the problem includes mathematical and graphical representations. In a similar vein, after analysis of 400 students' data, Meltzer (2005) asserted that students' problem-solving accomplishment depended strongly on their understanding of representations. Furthermore, he asserted that students fail to solve similar physics problem presented with different modal representations. He called this phenomenon "potential interrepresentational discrepancies" (p.473).

While there have been several physics education studies which focused on representational discrepancies on problem solving, the number of studies that investigate ways to increase student representational competencies and consequently understanding of the concepts in physics is limited. On the other hand, as argued by several researchers, the integration of multimodal representations such as text, graphs, mathematical terms, pictures, diagrams, and tables into writing to learn activities, can assist students in developing both modal competencies and fundamental ideas of science (Ainsworth, 2006; Hand, Gunel, \& Ulu, 2009). Guided by the current literature, the purpose of this study was two folded; firstly, to find effective activities that can help students to extend their understanding of modal representations and, secondly, to explore the multimodal representations that college students find effective and use in learning four modern physics units. 


\section{Method}

Research Design

A mixed-method approach including the survey method and interpretive qualitative case method with a quantitative (survey) and quantitative (interviews) data was adopted for this study. The survey method approach includes a group of data collection methods, which highlight quantitative analysis (McMillan \& Schumacher, 2010). The data would be collected from a large sample to make general inference to population or the data could be collected from a focus group to uncover the groups' characteristics (McMillan \& Schumacher, 2010; Williams, 2007). Semi-structured interviews were conducted with 6 students that were selected at random at the end of the study. Eighteen questions were asked in the interview and it lasted about thirty minutes. In our case, the survey data was collected from the students who had experienced the intervention concerning multimodal representations. Furthermore, this study also has the characteristics of basic interpretive qualitative research and case studies in which the researchers made data collection to discover the participants' understanding of instructional intervention as well as the value of modal representation in studying modern physics units (McMillan \& Schumacher, 1997).

Research Sample

The participant students were selected through non-probability sampling method and the sampling has the characteristics of convenience sampling. This type of sampling involves the sample being drawn from that part of the population, which is close to hand. That is, readily available and convenient. Within this framework, the above mentioned sampling method was the suitable way of identifying the sample since the instructor and co-author of the manuscript was offering a modern physics course in the same institution with the participating students. This study was carried out with 80 sophomore college students in Turkey within two identical sections of introductory modern physics for education majors course in the spring semester. The course instructor was the same for all students.

\section{Research Instrument and Procedure}

Throughout the semester, all students received the same instruction, covered the same instructional materials, and completed the same three assignments. The assignments were designed as worksheets to be completed by the class an as a homework assignment.

With the first assignment, students were asked to evaluate modal representations in two modern physics-related articles (taken from a monthly published national journal that publishes popular science articles for high school and college students) and two book pages from the modern physics textbook written by Yildiz (2004). While the reading part of the assignment was done outside of the class, the abovementioned evaluations were conducted within 50-minute instruction periods.

In this assignment, students in small groups were asked to make a list of multimodal representations (e.g., mathematical formula, picture, graph and text) used in written texts, then ask to record ways that modes were combined together to display 
science ideas. Afterwards, in a large group discussion with note taking, the following questions were teased out for the materials evaluated;

1. What are the effective modes used in those written materials? Why?

2. In what ways are modes related to each other or among themselves?

3. Which mode or modes helped us to learn about the topic/subject? Why?

4. How should we use mode or modes together (embedding) to best display our understanding?

With the second assignment, working in small groups, students were asked to examine the rubric that was handed to them by the instructor. The multimodal evaluation rubric used in this assignment was taken from McDermott's (2009) study in which he asked students to analyze chemistry-based written texts. In our study, by using their understanding of multi modal representation, students examined and discussed the given rubric and made any modifications they deemed necessary. Furthermore, in small groups they attempted to evaluate one of the science articles used in first assignment with their rubric. The review results and students ideas concerning how they adapted and used the rubric in the evaluation process were also discussed. There was another 50-minute instruction period spent on this assignment.

As a final assignment, students individually prepared a large poster with modal representations to display their learning on several modern physics units. Units included in this poster were light, photo electricity, the Compton Effect, and de Broglie wave length. The instructor provided an extra week for the students to think about evaluating written products by using the rubric given with the second assignment and to make any necessary changes on their poster. Surveys and semi-structured interviews were conducted to investigate the students' ideas on effective modal representations in learning the four units and in the three assignments. In the survey, students were asked to note the five most effective modes for learning each unit and also asked to state the modes that they used in their poster.

\section{Data Analyses}

The data obtained from the survey were analyzed in order to investigate students' perceptions toward interventions, the value of modal representations they had encountered during the instruction, and the value of modal representations they used with writing activity. The frequency analyses as a quantitative evaluation were conducted for the survey data (Sheskin, 2004). The survey data were examined to ascertain students' ideas about the value of a particular mode in studying the four units. Based on the analyses and histograms plotted, several tables were generated to demonstrate student responses to the ranking the five modes for each unit.

The researchers examined the transcripts from the interviews to identify main themes to be used in coding the data. The data were coded by using NVivo 8. Using NVivo helps in the analysis and writing the report due to its capacity to store useful words, phrases, and dialogues that allow the researcher to visualize the data and combine information from one category to another category (Soklaridis, 2009).

The numbers of agreements and disagreements were determined and the internal reliability of research was determined by using the reliability agreement/agreement 
+ disagreement formula" (Miles \& Huberman, 1994). Using this reliability calculation, the item agreement percentage of the scale was 0.93. As the researchers had agreed on the main categories, a list of these codes was prepared. The list is provided with the Table 1.

\section{Table 1}

The Themes and Codes for Interview Results

\begin{tabular}{|c|c|c|c|c|c|c|c|}
\hline Themes & Codes & S1 & S2 & S3 & $S 4$ & S5 & 56 \\
\hline \multirow{8}{*}{$\begin{array}{l}\text { The value of } \\
\text { assignments } \\
\text { in learning } \\
\text { modes }\end{array}$} & $\begin{array}{l}\text { The multimodal representations were } \\
\text { encountered but their functions were not } \\
\text { thought by students in the past }\end{array}$ & + & + & + & + & + & - \\
\hline & $\begin{array}{l}\text { The development of reading } \\
\text { comprehension }\end{array}$ & + & - & + & - & + & - \\
\hline & $\begin{array}{l}\text { The awareness of modal representation } \\
\text { used in science with first assignment }\end{array}$ & + & + & + & + & + & + \\
\hline & $\begin{array}{l}\text { The generation of meaning through modal } \\
\text { representation in science with first } \\
\text { assignment }\end{array}$ & - & + & + & - & + & - \\
\hline & $\begin{array}{l}\text { Improvement of their critical reading skills } \\
\text { with first assignment }\end{array}$ & + & - & + & - & + & - \\
\hline & $\begin{array}{l}\text { The implementation of the second stage } \\
\text { group activity contributed to students' } \\
\text { "competency of reading, understanding } \\
\text { and writing about science based text" }\end{array}$ & + & - & + & + & + & + \\
\hline & $\begin{array}{l}\text { The first and second assignments helped } \\
\text { them to craft their own writing }\end{array}$ & + & - & + & + & + & + \\
\hline & $\begin{array}{l}\text { The third assignment (embedding modal } \\
\text { representations into writing process) } \\
\text { assisted students to learn the topic }\end{array}$ & + & - & + & + & + & + \\
\hline $\begin{array}{l}\text { The value of } \\
\text { modes in } \\
\text { learning units }\end{array}$ & $\begin{array}{l}\text { The use of representations to scaffold } \\
\text { understanding of the topic. }\end{array}$ & + & + & + & + & + & + \\
\hline $\begin{array}{l}\text { Used modal } \\
\text { representatio } \\
\mathrm{ns} \text { in the } \\
\text { writing } \\
\text { activity }\end{array}$ & $\begin{array}{l}\text { Representations are appropriate ways to } \\
\text { make abstract concepts concrete for them } \\
\text { and their audience }\end{array}$ & + & + & + & + & + & + \\
\hline
\end{tabular}

+ : The opinion was commented, - : The opinion was not commented, S1: Student 1 


\section{Results}

Results were grouped into three sections. In each section, the results are represented under the subcategories of survey findings and interview findings. The first group of results presents students' ideas concerning the value of the three completed assignments in learning the meanings and functions of modal representations. The second part shows students' ideas about the value of a particular mode in learning these physics units. The third and final part focuses on students' use of modal representations in their writing-to-learn activity (poster). Due to space limitation, only the important results are provided here.

The Value of Assignments in Learning Modes

1st Assignment: Identifying modes and their functions in the written text

The frequency survey analyses of students' responses yielded the statistic that $92.6 \%$ of the students agreed that completing the first assignment (where they identify the function of modes and the relationship among the modes in constructing meaning with regard to science articles) was valuable in extending their understanding of modes and their roles in communicating ideas (3.7\% somewhat agree, $50.6 \%$ agree, $38.3 \%$ totally agree). Furthermore, $98.8 \%$ of the students indicated that completing the first assignment helped them organize their ideas about how to use multimodal representations in order to communicate science concepts $(3.7 \%$ somewhat agree, $55.6 \%$ agree, $39.5 \%$ totally agree).

During the interviews students were asked to elaborate their experiences in relation to their understanding of modal representation and the assignment completed. The theme analyses pointed out the general trend of "awareness of modal representations and their functions in communication" as an impact of the whole process. In general, students indicated that they had encountered the multimodal representations in various situations and although they had paid attention to some of the modal representations in past encounters, they had not tended to think about their functions in communication or meaning making. Furthermore, the responses of the students also raised the theme of "development of reading comprehension" with the awareness of the modal representations. Some of the exemplary responses were given below.

S 3: After completing the assignment there were things changed in my reading. I feel like I am trying to associate things (text, formula, picture, diagrams etc.) given within the written material. Also, I realized that reading is a joyful activity since you tend to make connection among the things.

Student during the interviews elaborated that, with the first assignment completed in this study, they recognized the modal representation used in science, the generation of meaning through modal representation in science and improvement of their critical reading skills. The overarching theme of the students' responses regarding the impact of the completion of the assignment was the "contribution of the modal representation in constructing meaning" especially in science. Some of the exemplary responses are given below. 
S 1: I was reading science articles in the past without paying any attention to what was used, what was the function of the components, if it was appropriate to use it and if it was contributing to the general meaning. This assignment pushed me to think about those questions. I think it helped me to understand how to read and understand an article. Also, it helped me to understand how I can communicate the ideas of an article to someone else after reading it.

$2^{\text {nd }}$ Assignment: Evaluating the appropriateness of the modes in the written text

For the second assignment, $98.8 \%$ of the students indicated that the numerical evaluation of modes and discussions within a small group helped to scaffold their understanding and effective usage of modes (15.9\% somewhat agree, 56.1\% agree, $26.8 \%$ totally agree). Similarly, the second stage activity helped $97.5 \%$ of the students to identify what they know and do not know about the topic mentioned in the text (14.6\% somewhat agree, $54.9 \%$ agree, $28.0 \%$ totally agree).

The interview results from the questions that investigated the impact of the second stage appear to focus more on the general literacy skills of students rather than the understanding of the topic content. That is, while the survey results indicate that by conducting the evaluation activity helped students to learn the science concept given with the material, the interview results pointed out that implementation of the second stage group activity contributed to students" "competency of reading, understanding and writing about science based text" with embedded modes. Some of the students' quotes are given below.

S 6: Somehow I am more aware of modal representations given not only in books but also in newspapers and magazines. Interestingly, I found myself judging the contribution of the individual mode to the meaning. I say: 'this is not necessary, this is good, helps to understand, why is it here not there?

During the interviews students made several attributions to the first and second assignments being valuable experiences as they were preparing their posters. The overarching theme of the students' responses was that identifying modes in the written materials, investigating their functions, and evaluating their contribution to the general meaning and their understanding helped them to craft their own writing (in the third assignment). Having experiences of the nature of those provided with the first and second assignments in relation to modal representations not only improves competency in reading about science but also it "provides a semiotic tool for writing about science". Some exemplary students' views about the impact of first two stages are provided below;

S 2: They [Assignments 1 \& 2] were helpful in learning what, why and how I can use the modes. I feel like I constructed my poster by knowing conceptually how to do it. I am sure if I had done it without doing other assignments, it would have portrayed silly things.

$3^{\text {rd }}$ Assignment: Construction of written material with embedded modal representation 
For the third assignment, $100 \%$ of the students indicated that preparing a poster with different modal representations increased their knowledge about the areas of modern physics that they had included in their posters. Finally, $97.6 \%$ of the students said that preparing a poster in this course facilitated their learning $(12.2 \%$ somewhat agree, $50.0 \%$ agree, $35.4 \%$ totally agree).

During interviews, students were asked to elaborate their learning experiences throughout the poster preparation activity. The most evident theme that came out of the student interviews was "embedding modal representations into writing process assisted students to learn the topic." Overall, students stressed the value of interweaving different modes into their writing in order to communicate with the audience. The impact of such attempts enhanced students' own understanding of the topic which they were trying to communicate. That is, as they were writing with modal representations to explain what they have learned, the activity not only enhanced their understanding of the modal representation but also developed their conceptual knowledge of the science topic communicated. Some of the students' quotes are given below.

S 4: I think this particular assignment [Poster preparation] had a significant impact on my learning... I think it affected my overall grade in this course....It was difficult to do it, I had a hard time conceptualizing it... At the end of the semester I was being able to construct meaning by examining graphs, formula, texts, etc.

The Value of Modes in Learning Units

When students were asked to identify the most valuable mode in studying four modern physics units, their responses appear as in the table below. Table 2 shows that students that participated in this study found the pictorial mode to be the most valuable in studying the light, photo-electricity, and Compton effect units. On the other hand, students designated the textual mode as the most valuable mode for learning de Broglie unit. Further, it was found that the animation type of representations have the third highest value for the Photo-electricity and Compton effect topics for the students in their learning. 
Table 2

Frequencies and Percentages of Modes Found Most Beneficial in Learning Modern Physics Units

\begin{tabular}{|c|c|c|c|c|c|c|c|c|c|}
\hline \multirow[b]{2}{*}{ Unit/Mode } & \multirow[b]{2}{*}{$f / \%$} & \multicolumn{8}{|c|}{ Modal Representations } \\
\hline & & Text & Picture & Math. & Graph & Table & Diagram & List & Animation \\
\hline Light & $f / \%$ & $22 / 26.8$ & $45 / 54.9$ & $1 / 1.2$ & $1 / 1.2$ & $0 / 0$ & $1 / 1.2$ & $0 / 0$ & $9 / 11$ \\
\hline $\begin{array}{l}\text { Photo- } \\
\text { electricity }\end{array}$ & $\mathrm{f} / \%$ & $18 / 22.0$ & $45 / 54.9$ & $2 / 2.4$ & $2 / 2.4$ & $0 / 0$ & $0 / 0$ & $0 / 0$ & $12 / 14.6$ \\
\hline $\begin{array}{l}\text { Compton } \\
\text { effect }\end{array}$ & $f / \%$ & $19 / 23.2$ & $47 / 57.3$ & $0 / 0$ & $0 / 0$ & $0 / 0$ & $1 / 1.2$ & $0 / 0$ & $11 / 13.4$ \\
\hline $\begin{array}{l}\text { de Broglie } \\
\text { wave } \\
\text { length }\end{array}$ & $f / \%$ & $36 / 44.4$ & $30 / 37.0$ & $3 / 3.7$ & $1 / 1.2$ & $0 / 0$ & $1 / 1.2$ & $0 / 0$ & $4 / 4.9$ \\
\hline
\end{tabular}

Concurrently, students were asked to identify the second and third most valuable mode in learning those modern physics unit. Students indicated that they found the textual mode to be the second most valuable in their study of all units stated. Their responses appear in Table 3 below. Further, it was found that while graphical type of representations have the third highest value for the light unit, mathematical type of representations have the third highest value for the Photo-electricity Compton effect and de Broglie wave length topics for the students in their learning.

\section{Table 3}

Frequencies and Percentages of Modes Found Second Most Beneficial in Learning Modern Physics Units

Modal Representations

\begin{tabular}{lccccccccc} 
Unit/Mode & $f / \%$ & Text & Picture & Math. & Graph & Table & Diagram & List & Animation \\
\hline Light & $\mathrm{f} / \%$ & $28 / 34.1$ & $22 / 26.8$ & $0 / 0$ & 9 & $3 / 3.7$ & $3 / 3.7$ & $0 / 0$ & $6 / 7.3$ \\
$\begin{array}{l}\text { Photo- } \\
\text { electricity }\end{array}$ & $\mathrm{f} / \%$ & $26 / 31.7$ & $25 / 30.5$ & $8 / 9.8$ & $5 / 6.1$ & $3 / 3.7$ & $4 / 4.9$ & $0 / 0$ & $7 / 8.5$ \\
$\begin{array}{l}\text { Compton } \\
\text { effect }\end{array}$ & $\mathrm{f} / \%$ & $29 / 35.4$ & $23 / 28$ & $13 / 15.9$ & $4 / 4.9$ & $2 / 2.4$ & $1 / 1.2$ & $1 / 1.2$ & $3 / 3.7$ \\
$\begin{array}{l}\text { de Broglie } \\
\text { wave length }\end{array}$ & $\mathrm{f} / \%$ & $21 / 25.6$ & $20 / 24.4$ & $20 / 24.4$ & $4 / 4.9$ & $2 / 2.4$ & $1 / 1.2$ & $0 / 0$ & $1 / 1.2$ \\
\hline
\end{tabular}




\section{Table 4}

Frequencies and Percentages of Modes Found Third Most Beneficial in Learning Modern Physics Units

\begin{tabular}{lccccccccc} 
& & \multicolumn{7}{c}{ Modal Representations } \\
\cline { 3 - 9 } & & & & & \\
Unit/Mode & $f / \%$ & Text & Picture & Math. & Graph & Table & Diagram & List & Animation \\
\hline Light & $\mathrm{f} / \%$ & $13 / 15.9$ & $7 / 8.5$ & $15 / 18.3$ & $8 / 9.8$ & $4 / 4.9$ & $5 / 6.1$ & $0 / 0$ & $4 / 4.9$ \\
$\begin{array}{l}\text { Photo- } \\
\text { electricity }\end{array}$ & $\mathrm{f} / \%$ & $14 / 17.1$ & $2 / 2.4$ & $16 / 19.5$ & $17 / 20.7$ & $2 / 2.4$ & $5 / 6.1$ & $1 / 1.2$ & $4 / 4.9$ \\
$\begin{array}{l}\text { Compton } \\
\text { effect }\end{array}$ & $\mathrm{f} / \%$ & $12 / 14.6$ & $5 / 6.1$ & $25 / 30.5$ & $9 / 11.0$ & $3 / 3.7$ & $5 / 6.1$ & $1 / 1.2$ & $0 / 0$ \\
$\begin{array}{l}\text { de Broglie } \\
\text { wave length }\end{array}$ & $\mathrm{f} / \%$ & $8 / 9.8$ & $11 / 13.4$ & $7 / 8.5$ & $7 / 8.5$ & $2 / 2.4$ & $5 / 6.1$ & $0 / 0$ & $0 / 0$ \\
\hline
\end{tabular}

Analyses of the interview data yielded results that were parallel to the survey findings. That is, in learning those modern physics subjects during the instruction, students found pictorial, textual and mathematical representation to be highly significant, although they were exposed a variety of different modes throughout the topics. It appears that "students used particular representation to scaffold their understanding of the topic." While the text was the predominant medium to elaborate concepts, the pictorial representations help them to visualize what has been conveyed through the text. On the other hand, the mathematical representation seems to function as a derivative way of explaining the concept.

S 5: For modern physics, I think text and picture are necessary to understand the topic. Formulas are important but not always. Graphs are okay, yet it has to be very clear and understandable, otherwise it's not good for me.

Modal Representations in the Writing Activity

When students were asked to embed modal representations in their writing-tolearn activity (poster) they used variety of representations. Hence, when they were asked to identify modal representations which they found to be important and used in their poster, their responses appeared as in the Table 5 below. As the first priority, $68.4 \%$ of the participating students preferred to use pictures in their poster in order to communicate science ideas they wanted to portray. Likewise, $51.3 \%$ of the students preferred to use text as the second priority and $33.3 \%$ of the students preferred to use mathematical formulas as a third priority in their poster.

During the interviews, students emphasized that the textual and mathematical representations were their preferences to be embedded in their posters. Such preferences were evident with the survey results. When they were asked to elaborate their 
preferences as to which modes were to be used in the posters they indicated, "Textual and pictorial representations are appropriate ways to make abstract concepts concrete for them and their audience." Unpacking the concepts within short paragraphs or bullets and visualizing the abstract concepts with pictorial representations appear to be the underlying logic behind the high frequency of usage with regard to those two particular modal representations. Students indicated that:

\section{Table 5}

Frequencies and Percentages of Modes That Student Used Their Writing-To-Learn Activity

\begin{tabular}{|c|c|c|c|c|c|c|c|c|c|}
\hline \multirow[b]{2}{*}{ Priority } & \multirow[b]{2}{*}{$f / \%$} & \multicolumn{8}{|c|}{ Modal Representations } \\
\hline & & Text & Picture & Math. & Graph & Table & Diagram & List & Animation \\
\hline 1.priority & $\mathrm{f} / \%$ & $17 / 22.4$ & $52 / 68.4$ & $1 / 1.3$ & - & $1 / 1.3$ & $2 / 2.6$ & - & $3 / 3.9$ \\
\hline 2.priority & $f / \%$ & $39 / 51.3$ & $18 / 23.7$ & $5 / 6.6$ & $10 / 13.2$ & $2 / 2.6$ & $1 / 1.3$ & - & $1 / 1.3$ \\
\hline 3.priority & $\mathrm{f} / \%$ & $5 / 6.9$ & $6 / 8.3$ & $24 / 33.3$ & $21 / 29.2$ & $2 / 2.8$ & $10 / 13.9$ & $2 / 2.8$ & $2 / 2.8$ \\
\hline
\end{tabular}

S 6: I used mostly text because I think I learn a lot with reading the text. Also, I started to think about pictures that can accompany what I have written. They were kind of a supporting element to my ideas. They were connected with my text.

\section{Discussion and Conclusion}

The physics education literature offers several studies that investigate the value of using multimodal representations within writing-to-learn activities to promote content understanding (Gunel, et al., 2009; Prain \& Waldrip, 2006). However, the literature is limited with regard to guiding how to increase students' competencies with multimodal representations. Moreover, as emphasized by Airey and Linder, (2009) studies that explore students' views about effective modal representations in learning physics units are also absent in the literature.

With this study, it is first aimed to explore effective activities that can help students to extend their understanding of modal representations. To do that, we followed a 3-step instructional design. In the first step, we have found that the learning about, and use of, multimodal representation linked to writing-to-learn strategies assisted students in constructing understanding of science concepts. Around $95 \%$ of the participating students stated that assignments, where they explored the function and effectiveness of the modalities in science, did assist them in understanding multimodal representations in science. Further, more than $90 \%$ of the students indicated 
that preparing a poster with embedded multimodal representations helped them learn the concepts and helped them recognize what they did and did not know.

Students elaborated that through the intervention, they developed understanding about the impact modal representations have on the construction of meaning in science. While there are several quantitative studies in the literature, which argue for learning enhancement through concrete understanding using modal representations (McDermott, 2009; Gunel, et al., 2009), this study provided qualitative evidences in accordance with the empirical findings available. Furthermore, having gone through such hand-on experiences increased students' awareness of modal representations and their functions in communicating science ideas. The students being able to understand the function of the language components and their role in communication (Lemke, 2004) acts as evidence that the intervention had an impact on both students' literacy and science literacy skills.

The interview results that point to the reading and writing comprehensions are also worthy of further discussion. The themes generated through interview data were that the competencies of reading, understanding and writing about sciencebased texts and the development of reading comprehension. The above-mentioned competencies and comprehensions are the ultimate goals for most subject curriculum. Furthermore, they are subjects, which are evaluated by international tests such as TIMMS and PISA among the OECD member countries. In the past, the performance of Turkish students in those measurements was noted to be low in both the areas of science and reading comprehension (Çelen, Çelik, \& Seferoğlu, 2010; Özenç, \& Arslanhan, 2010). Although this particular study has too many limitations to make generalizations based upon it, one would argue our educational practices need to pay more attention to pedagogical and instructional interventions which scaffold students' reading and writing competencies within the subject matter, as was the case with the topic of science in this study. In short, we would argue that simple instructional designs similar to the one applied in this study can be implemented in physics classrooms to promote content understanding, to extend literacy skills and to boost students modal competencies as has been pointed out by Meltzer (2005).

The study also aimed to explore the multimodal representations that college students find effective and use in studying modern physics units. To explore this objective, we wanted to first provide rich experiences in order for students to understand and identify modes, then to give the opportunity to use modes in a learning activity, as discussed above. Thereafter, we asked students to rank-order the value of these modal representations in studying those units. They indicated that, for almost all units covered in this study, text and pictures were the most valuable modes. Interestingly, the animation type of modal representation had the third highest-ranking value for the first choices in studying Photo-electricity and Compton effect topics. While students were exposed to the animation throughout all of the subtopics, they found the animations displayed particularly valuable for those two topics in the class. We speculate that the results appeared in that way for two reasons. First, students' found the animations valuable due to the nature of the topics. As we discussed below, the more the topic abstract to them the more pictorial or in this case animated represen- 
tation they may need. Second, the conceptual quality of the animations might be better than those displayed for the other topics.

These findings are important in two ways. Firstly, regardless of the rank, they are one of the first attempts to try to figure critical consultation of modes (Airey \& Linder, 2009) from the students' perspective. Secondly, unlike in units such as classical mechanics and electricity (Gunel, et al., 2009; Hand et al., 2009; McDermott, 2009), to learn modern physics units, a combination of text and pictures becomes important for college students. Furthermore, as in the case of the Photo-electricity and Compton effect topics, the more abstract topics may call for animated types of modal representations. More interestingly, when students were asked to use representations in their writing-to-learn activity (poster), they indicated that their modal preferences for communicating modern physics ideas were, again, picture and text. This is an indication that students tend to find textual and pictorial representations more valuable than other modes in learning those modern physics units.

Students' elaboration about modal preferences in learning modern physics units pointed out the theme of "Textual and pictorial representations are appropriate ways to make abstract concepts concrete for them and their audience." One could argue that the nature of the concept studied requires a sense of transformation from being abstract to concrete. While students have very limited opportunity to conduct experimental work or to bring their experience-rich prior knowledge about the topic, they tend to enhance their textual-in some way factual-knowledge with visual representation in order to create a deeper understanding of the concept (Verschaffel, 2010).

In conclusion, the crucial implication of these findings, in practice, is that in teaching introductory level modern physics units, university lecturers may need to pay special attention to making connections between those modes. Furthermore, when students were asked to do assignments of writing activities to scaffold understanding, they may have been directed towards make meaningful connection between pictorial and textual representations. What is more, increasing awareness of multi modal representation and embedding modal representations into writing-tolearn activities can serve as a strong heuristic to enhance literacy competencies as well as acting as a scaffolding tool to develop deeper content understanding. In short, both students' understanding of physics and their literacy skills can be boosted with proper use of modal representation when the physics education community is aware of the function of modes not only "to communicate science" but also "to do and learn science".

\section{References}

Ainsworth, S. (2006). DeFT: A conceptual framework for considering learning with multiple representations. Learning and Instruction, 16, 183-198.

Airey, J. \& Linder, C. (2009). A disciplinary discourse perspective on university science learning: Achieving fluency in a critical constellation of modes. Journal of Research in Science Teaching, 1(46), 27-49. 
Çelen, F. K., Çelik, A., \& Seferoğlu, S.S. (2011). Türk eğitim sistemi ve PISA Sonuçları. Akademik Bilişim 2011. İnönü Üniversitesi, Malatya.

Gunel, M., Atila M. E., \& Buyukkasap E. (2009). The impact of using multi modal representations within writing to learn activities on learning electricity unit at 6th grade. Elementary Education Online, 8(1), 183-199.

Gunel, M., Hand, B., \& Prain, V. (2007). Writing for learning in science: A secondary analysis of six studies. International Journal of Science and Mathematics Education, 5(4), 615- -637.

Hand, B., Gunel, M., \& Ulu C. (2009). Sequencing embedded multimodal representation in a writing to learn approach to the teaching of electricity. Journal of Research in Science Teaching, 3(46), 225-247.

Hand, B., Prain, V., Lawrence, C., \& Yore, L. D. (1999). A writing in science framework designed to enhance science literacy. International Journal of Science Education, 21 (10), 1021-1035.

Kohl, P. B. \& Finkelstein, N. D. (2005). Student representational competence and selfassessment when solving physics problems. Physical Review Special Topics Physics Education Research, 1(1), 010104.

Lemke, J. (1998). Multiplying meaning: Visual and verbal semiotics in scientific text. In J. Martin \& R. Veel (Eds.), Reading science: Critical and functional perspectives on discourses of science (pp 87-113). London: Routledge.

Lemke, J. (2004). The literacies of science. In W. Saul (Ed.), Border Crossing: Essays on Literacy and Science. Newark, DE: International Reading Association.

McDermott, M. (2009). The impact of embedding multiple modes of representation on studetn construction of chemistry knowledge. Unpublished Doctoral Dissertation, University of Iowa

McMillan, J.H. \& Schumacher, S. (1997). Research in education: A conceptual introduction (4th ed.). New York: Longman.

McMillan, J. H. \& Schumacher, S. (2010). Research in education: Evidence-based inquiry.(7th ed.). Boston, MA: Pearson.

Meltzer, D. E. (2005). Relation between students.problem-solving performance and representational mode. American Journal of Physics, 73 (5), 463-478.

Miles, M. B. \& Huberman, A. M. (1994). Qualitative data analysis. USA: Sage Thousand Oaks.

Norris S. P. \& Phillips, L. M. (2003). How literacy in its fundamental sense is central to scientific literacy. Science Education, 87 (2), 224-240.

Özenç, B. \& Arslanhan, S. (2010). PISA 2009 sonuçlarnna ilişkin bir değerlendirme. Türkiye Ekonomi Politikaları Araştırma Vakfı.

Prain, V. \& Hand, B. (1999). Students perception of writing for learning in secondary school science. Science Education, 83(2), 151-162.

Prain, V. \& Waldrip B. (2006). An exploratory study of teachers' and students' use of multi-modal representations of concepts in primary science. International Journal of Science Education, 28(15), 1843-1866.

Sheskin, D. (2004). Handbook of parametric and nonparametric statistical procedures (3rd ed.). Boca Raton, FL: Chapman \& Hall/CRC. 
Soklaridis, S. (2009). The process of conducting qualitative grounded theory research for a doctoral thesis: Experiences and reflections. The Qualitative Report, 14 (4), 719-734.

Verschaffel, L. (2010). Use of external representations in reasoning and problem solving : analysis and improvement (2nd ed.). New York: Routledge.

Williams, C. (2007). Research methods. Journal of Business E Economic Research, 5 (3), 65-72.

Yıld1z, A. (2004). Modern physics for elementary education majors. Türkiye: Gündüz Eğitim ve Yayıncilık.

Yore, L. D., Bisanz G. L., \& Hand, B. (2003). Examining the literacy component of science literacy: 25 years of language arts and science research. International Journal of Science Education, 25(6), 689-725.

\section{Üniversite Öğrencilerinin Modern Fizik Öğrenme Sürecinde Modsal Betimlemeler ve Öğretimi Etkinliği Hakkındaki Algıları}

Atıf:

Yeşildağ Hasançebi, F., \& Günel, M. (2013). College students' perceptions toward the multi modal representations and instruction of representations in learning modern Physics. Egitim Arastirmalari-Eurasian Journal of Educational Research, 53, 197-214.

\section{Özet}

Problem Durumu: Yazma aktiviteleri bilginin gösteriminden çok öğrencileri içine alan bir öğrenme aracı olarak düşünülmekte ve öğrencilerin günlük dilleri ile bilim dili arasında bağlantı kurmalarına yardımcı olmaktadır. Yazma aktiviteleri içine metin, grafik, tablo, resim, diyagram, liste, matematiksel ifade gibi modları içeren modsal betimlemeler kullanıldığında öğrenciler üzerinde çalışılan üniteyi kapsamlı ve derinlemesine öğrenmektedir.

Son yıllarda öğrenme üzerine yapılan araştırmaların bir kısmında çoklu modsal betimlemelerin önemi vurgulanmıştır. Yapılan araştırmalar, özellikle matematik ve fen alanlarında öğrenenlerin uygun betimlemeler ile etkileşim içinde bulunmalarının performanslarını artığını göstermektedir. Dahası modsal betimlemeler kullanılırken belli modlara bağlı kalınmasından ziyade farklı modların anlaşılması ve kullanılmasının daha etkili sonuçlar doğurduğu tespit edilmiştir. Öğrencilerin her bir betimlemenin özelliğini bilerek bunlardan yararlanması onların konuyu derinlemesine anlamasını sağlamaktadır. Bu bağlamda çalışmanın odak noktası modsal betimlemeleri etkili öğrenmeyi sağlamak, kullanma ve anlama süreci ile birlikte modern fizik konularını öğrenmede hangi mod/modların öğrenciler tarafından etkili bulunduğunun araştırmaktır. 
Araştırmanın Amacı: Bu çalışmanın iki amacı vardır. Bunlardan birincisi, modsal betimlemeleri anlamaları için öğrencilere yardımcı olabilecek aktivitelerin etkisini ortaya çıkarmak, ikincisi ise üniversite

öğrencilerinin modern fizik konularını öğrenmede etkili gördükleri ve kullandıkları modsal betimlemeleri belirlemektir.

Araştırmanın Yöntemi: Araştırmanın örneklemini Türkiye'nin doğusundaki bir üniversitede modern fizik dersini alan 80 fen bilgisi öğretmenliği bölümü öğrencisi oluşturmaktadır. Çalışma modern fizik dersinde 1şık, foto elektrik, Compton olayı ve de Brogie dalga boyu konularında uygulanmıştır. Uygulama boyunca, bütün öğrenciler dönem içerisinde modları tanıma, kullanma ve değerlendirme adına 3 aşamalı süreci ortak olarak tamamlamışlardır. Öğrenciler 1. aşamada; bireysel olarak modları tanıma, analiz etme ve değerlendirme, 2 . aşamada; küçük bir grup içinde verilen bilimsel metin içerisindeki modsal betimlemeleri tartışarak değerlendirme ve 3. aşamada; bireysel olarak farklı modlardan faydalanarak film şeridi formatında poster hazırlama aşamalarını tamamlamışlardır. Araştırma deneysel olmayan bir dizayn çerçevesinde betimsel bir araştırmadır. Çalışmada anket ve yarı yapılandırılmış görüşmelerden elde edilen veriler analiz edilmiştir.

Araştırmanın Bulguları: Sonuçlar üç bölümde gruplandırılmış olup her bir bölümde anket ve görüşmelerden elde edilen bulgular sunulmuştur. Çalışmada öğrencilerin tamamlamış olduğu üç aşama değerlendirilmiştir. Öğrencilerin bu aşamalardan önce modlarla karşılaşmış oldukları fakat bunlardan sadece bazılarının onların dikkatini çektiği ve bunların hangi amaçla kullanıldıklarına dikkat etmedikleri belirlenmiştir. Ancak tamamlanan bu süreçlerle birlikte modsal betimlere farkındalık kazandıkları, okuma, yazma ve anlamalarının geliştiği tespit edilmiştir. Bilimsel makaleler üzerindeki modların işlevi ve modlar arasındaki ilişkinin incelendiği birinci aşama için öğrencilerin \%92.6'sı bu aşamanın bir düşünceyi aktaran modları ve modların rolünü anlamalarını sağladığını, \%98.8'i de modsal betimlemeleri nasıl kullanacakları hakkında onlara fikir verdiğini ifade etmişlerdir. Görüşme sonuçlarında da öğrencilerin ilk aşamayla birlikte modların neler olduğu, hangi modun ne amaçla ve nasıl kullanıldığ ${ }_{1}$ hakkında fikir sahibi olmaya başladığı, ve kritik okuma becerilerinin geliştiği belirlenmiştir. Bilimsel materyali ve üzerindeki modların değerlendirildiği ikinci aşama için öğrencilerin \%98.8'i modların etkili kullanılması ve anlaşılmasını kolaylaştırdığını ve \% 97.5'i de konu ile ilgili neyi bilip bilmediklerini anlamalarını sağladığını belirtmişlerdir.

Buna karşın görüşme sonuçları bu aşamanın fen içerikli bir metin yazma, anlama ve okuma yeterliliğine katkı sağladığına işaret etmektedir. Öğrenciler genel olarak bu aşamayı yararlı görmekte ve modlar hakkındaki fikirlerinin daha da geliştiğini ifade etmektedirler. Ayrıca bu iki aşamanın yalnızca fen ile ilgili okuma için yeterlik sağlamadığını aynı zamanda fen ile ilgili yazma için de bir araç sağladığını vurgulamışlardır. Farklı modları bir araya getirip poster oluşturma aşaması olan üçüncü aşama için ise öğrencilerin \%100'ü bu uygulamanın modern fizik konuları hakkında bilgilerini artırdığını belirtmişlerdir. Görüşme sonuçları da bununla paralellik göstermekle birlikte bu aşamanın öğrencilerin bağlantı kurmaya çalıştıkları fen konuluları ile ilgili 
kavramsal bilgilerini geliştirdiğini göstermektedir. Ayrıca öğrencilerin modern fizik konularını öğrenmelerinde kolaylık sağlayan modları belirlemeleri istenmiştir. Ö ̆̆renciler tarafından ışık, foto elektrik ve Compton olayı konularını öğrenmede en etkili mod resim seçilirken, de Brogie konusunu öğrenmede metin en etkili mod olarak tercih edilmiştir. Dahası Fotoelektrik ve Compton olayı konularını öğrenmede animasyon üçüncü önemli görülen mod türü olmuştur. Görüşme sonuçları da anket sonuçları ile benzerlik göstermektedir. Öğrencilere öğrenme amaçlı yazma aktivitelerinde (poster) hangi modları kullanmayı tercih ettikleri sorulduğunda ise öğrencilerin \%68.4'ü birinci öncelik olarak resim tercih ederken \%51.3' ü ikinci öncelikli mod olarak metni kullanmayı tercih etmiştir. Görüşmeye katılan öğrencilerin de özellikle resim ve metni önemli görüp posterlerinde kullandıkları belirlenmiştir.

Araştırmanın Sonuçları ve Önerileri: Araştırmanın birbiri ile paralellik gösteren anket ve yarı yapılandırılmış görüşme sonuçları düşünüldüğünde önemli bir tema ortaya çıkmaktadır. Bu tema; öğrencilere öğrenme amaçlı yazma aktiviteleri ile birlikte çoklu modsal betimlemeleri kullanma ve öğrenme fırsatı verilmesi fen konularını anlamalarında onlara yardım etmektedir. Süreç içerisinde fende modsal betimlemelerin fonksiyonları ve etkilerini keşfettikleri aşamalar ( 3 aşama) ise onların modsal betimlemeleri anlamalarına yardımcı olmaktadır. Ayrıca modsal betimlemeleri içeren yazma aktiviteleri (poster, broşür, mektup) içeren fırsatlar öğrencilerin konuyu daha iyi anlamalarının yanında konu hakkında neyi bilip bilmediklerini görmelerini sağlamaktadır. Dahası elde edilen sonuçlar üniversite düzeyinde modern fizik konularının bir bölümünde öğrencilere gerek uygulamalarda gerekse dersin işleniş sürecinde modsal betimlemeleri içeren öğrenme fırsatları sağlandığında, resim ve metin modalarının konuların öğrenilmesinde en önemli modlar olduğunu göstermektedir. Bu durum modern fizik konularının okullarda uygulanması zor ya da mümkün olmayan deneysel çalışmaları içerdiği göz önüne alınırsa zengin kavramsal içerikli metinlerin ve resimlerin öğrenme üzerinde belirtilen birinci derecedeki faydası ile açıklanabilir. Bununla birlikte özellikle görüşme sonuçlarında dikkat çeken nokta bu süreç ile birlikte öğrencilerin okuma, anlama ve yazma yeterliliğinde gelişme meydana gelmesidir.

Bu çalışma hem fen eğitimi alanında teorik düşüncelere hem de pedagojik uygulamalara belli bir açıdan ışık tutmaktadır. Teorik anlamda, öğrenenlerin bilgiyi semantik olarak kodladığı düşüncesinden yola çıkıldığında (Lemke, 1998) modsal betimlemeler bilginin aktarımında ve zihinde yapilandırılmasında temel unsurdur ve fen öğretiminde öğrenme ortamlarının tasarlanmasında mutlaka dikkate alınmalıdır. Pedagojik anlamda, bu çalışmada öne sürülen, uygulanması kolay ama öğrenmede etkili ders içi ve dışı etkinlikler hem öğrenmeyi desteklemekte hem de öğrenci merkezli ders işlemede faydalı olmaktadır.

Anahtar Sözcükler: Çoklu modsal betimlemeler, öğrenme amaçlı yazma, modern fizik 